\title{
EVALUATION AND COMPARING THE LOSSES OF DIFFERENT JUICE PACKAGING RATES AND SYSTEMS IN THREE JUICE PLANTS
}

\author{
Hanafy W. M. *
}

\section{ABSTRACT}

This research was conducted to evaluate and compare the juice damaged packages, bottels and quantities of juice losses under different rates of packging processes. Six rates were studied in plant A and five rates in plant $B$ and $C$ for two different products of juices using tetra brick aseptic packaging machine (TP), vole pack packaging machine (VP) and Automatic vacuum filer/capper machine (AUV) in addition to quantities of juice losses. The damage juice packages, bottels and the quantity of juices losses accompanied with each rates in the plants were compared and the results cleared that the suitable machine rateses for different packaging system in plants.(A), $(B)$ and $(C)$.

Experiments cleared that the suitable machine rates were 6300 and 5460 pack/hr for TP. mango juice $200 \mathrm{ml}$ and $1000 \mathrm{ml}$ in plant A respectively, while they were 5460 and 5520 pack/hr for VP.240 mango and apple juice $130 \mathrm{gm}, 4860$ and $4800 \mathrm{pack} / \mathrm{hr}$ for VP.240 mango and apple juice $200 \mathrm{gm}$, they were 3540 and 3420 bottle/hr for AUV mango and apple juice $200 \mathrm{ml}$ in plant $B$ respectively, in addation to 3240 and $3540 \mathrm{pack} / \mathrm{hr}$ for VP. apple juice $130 \mathrm{ml}$ and $200 \mathrm{ml}$ in plant C respectively.

Key words: juice, plant, losses, saving, Tetra brick aspetic, Volpack, automatic vacuum filer/capper packiging machine.

\section{INTRODUCTION}

$\mathrm{P}$ acking operatesion is most important in juice processing. The losses of product and packaging represent an essential problem during packaging process Jean (2016) Saied that In the U.S. dairy industry, milk losses can average 2 to $3 \%$ from the time the raw milk enters the factory until the finished product is packaged and shipped.

\footnotetext{
*Lecturer, of Ag. Eng. Dept., Faculty Of Agric.and Natural Resources, Aswuan University.
} 
One solution is employing equipment designed to maximizing efficiency and minimizing product losses.

Egyptian E.A.A.I.M. (2015) founed that the estimated losses rate was 2\% for aseptic packaging machines which used in packaging sterilized milk. The sterilized milk packaged in Tetra Brick Aseptic portion packages validity period 6 months Compared to pasteurized milk filled in bottles of polyethylene validity period was a week only.

Hanafy $(r \cdot 10)$ studied that the packging losses for two different products named fluid milk and vita cheese using tetra brick aseptic packaging machine at different rates of packging processes in dairy plant. The result of the study revealed that the suitable machine rate for packaging milk volum $200 \mathrm{ml}, 500 \mathrm{ml}$ and $1000 \mathrm{ml}$ were $(7140,5160$, \& 6420) pack/h while the Vita cheese weight (250 and 500) gm were (5160\& 5040) pack/h in plant respectively.

OVAM (2015) reported that soft drinks losses during the syrup preparation and the filling process negligible percentage of loss $(<1 \%)$.

Dairy-technology (2014) mentioned that in the packing operatesion, losses are mostly due to over filling, spillage and failure of packing. In milk packing, the loss of 0.5 to $1.0 \%$ is general. The general reason for losses during packing is negligence, carelessness and safety margin due to stringent laws and machine sensitivity.

Wikipedia (2014) reported that aseptic packages are typically a mix of paper (70\%), polyethylene (LDPE) (24\%), and aluminum (6\%), with a tight polyethylene inside layer.

Organization (2012),reported that the most important consumer packaging are made of paper and board (38\%), followed by plastic (30\%) with rigid plastics alone taking an $18 \%$ share, metal (19\%), glass $(8 \%)$, and others $(5 \%)$.

UK Drinks sector (2010) reported that loss of product by overfilling occurs even with the most accurate filling equipment for one soft drinks company visited, visual fill losses accounted $1.3 \%$ yield loss. Improving filling efficiency dependent on the type of technology, age of the equipment and maintenance regimes in place. 
Wkieducator.org (2008) reported that packaging containers designed to protection materials from outside influences. Packaging materials were Paper which accounts for about $50 \%$ of all packaging. Glass is also has excellent barrier properties, transparent, reusable, reasonably strong, easy to open. Aluminum foil and polyethylene used for fruit juice, and soft drinks packaging while Tetra pack used for dairy products.

UNIDO (2004) reported that Typical losses during Packaging of fruits and vegetables with a percentage of loss 5-10.

Timothy and Jibing (1996) reported that factory lost glasses bottle of the finished product, normally $1.5 \%$ occurred during the production stages the finished product, losses occurred during production of glasses bottle is acceptable, but the factory's losses has reached 4-10 percent.

According to that.Thise study amied to evaluate and compare the volumes of damaged packages, quantity of product and electrical power losses during in packging processes for two product including TP (mango juice 200 and $1000 \mathrm{ml}$ ) by using six different ratese in plant (A) while two different product including VP 240 a (mango and apple juice) by using five different ratese packaging system such as (mango juice 130, $200 \mathrm{gm}$ and apple juice 130,200 gm) and two product including AUV (mango juice 200 and apple juice $200 \mathrm{ml}$ ) by using five packaging ratese also in plant (B) in addation to one product including VP (apple juice 130 and200 $\mathrm{ml}$ ) by using five packaging ratese in plant (C). On this study Quantity losses juice and electrical power in plant (A),(B) and (C) applied to compute damaged packages and bottels (bad welding,damaged bottles or not complete filled) and losses product in lines or uncompleat packages during packaging process will apper by change packaging machine ratese to determine the ratesio of packages damaged, product and elecrical power losses in this speed to choose the proper packaging machine ratese to reduce the losses .

\section{MATERIALS AND METHODS}

The experiments were carried out in three plants were "Green Land" Middle East Co.(A), "Tiba" Co. (B) and "Biela" Co. (C) plants for food production at $10^{\text {th }}$ of Ramadan City in the period from Jan., 2016 to Feb., 2016. 


\section{The specifications of different packing systems are:-}

\section{Plant A:}

\section{Tetra brick aseptic packaging machine:-Fig (1)}

The machine packaged liquid juice in tetera brick aseptic prortion packages with filler capacity ranged from 7500 to $6000(-0 \%+4 \%)$ per hour and volumes available all exisiting TBA/19 volumes.It has an automatic splicing unit with double reel for packaging material. In this study the experiments were carried out on TP mango juice for ${ }^{\text {volumes }} 200$ $\mathrm{ml}$ and 1 litter. The Juice pasteurized by (HTST) system, using hot water at temperatesure of $85{ }^{\circ} \mathrm{C}$ with holding time 30 seconds then The pasteurized juice sterilized by (UHT) system by steam at temperatesure $95^{\circ} \mathrm{C}$ with holding time 4 seconds. , after that, the product is cooled to 25 ${ }^{\circ} \mathrm{C}$ and pumped to packaging storage tank.

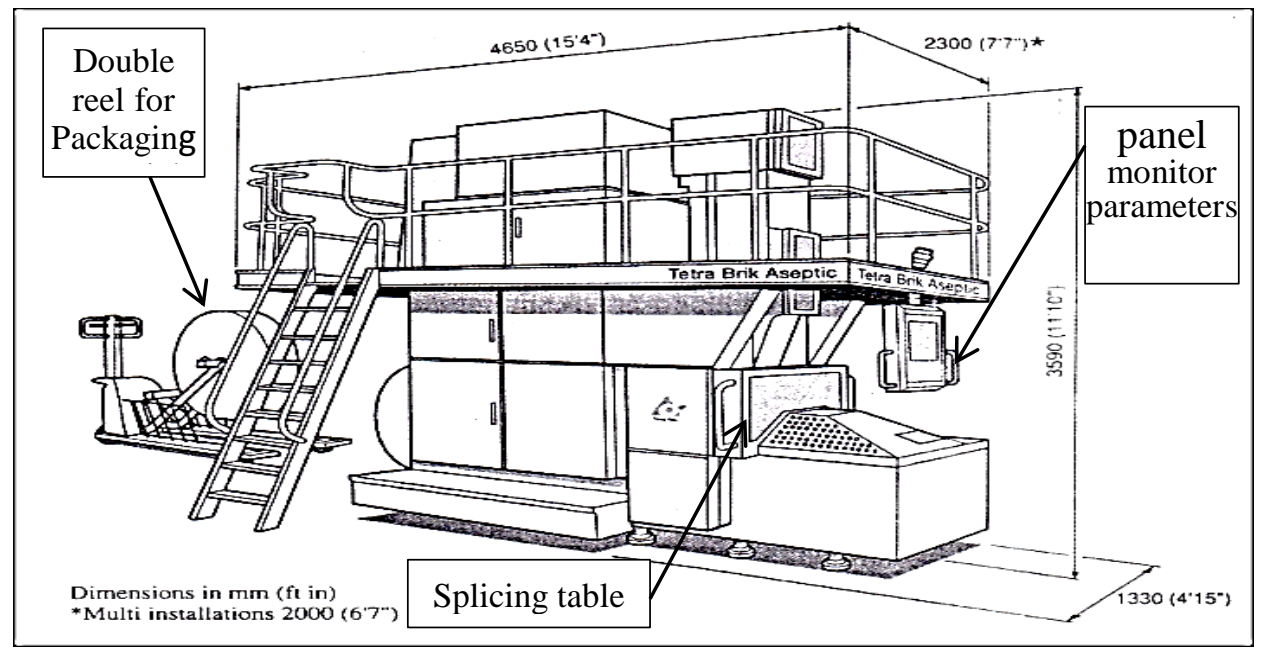

Fig. (1): Tetra brick aseptic packaging machine (Type: TBA/19-010V)

\section{Packaging depart and losses:}

Sterilized juice led to Tetra Brick Aseptic packaging machine to be packaged in Tetra Brick Aseptic portion packages.Packages are transported by conveyor to tubex straw applicator which provide the packages with tubex and transport by conveyor to tetra card board packer which collect packages in small groups in wrap around box, the box transported by conveyor to shrink machine to be wrapped the boxes with plastic cover, finally the product led to storage . 


\section{Plant B:}

\section{Vole pack machine (Type: 240):-Fig (2)}

The Vole pack machine is packed liquid food in vole packages and with filler capacity ranged from 4000 to $8000(-0 \%+5 \%)$ per hour and volumes available were $130 \mathrm{gm}$ and $200 \mathrm{gm}$.It was made of stainless steel and hardened glass frame. It's components are a one reel, automatic splicing unit for packaging material, buffer tank with level control, 4 axial welding knifes, 4 filling valves, stainless steel conveyor, pump and panel unit. In this study the experiments were carried out on VP mango and apple juice for volumes 130 and $200 \mathrm{gm}$. Juice pasteurization by (HTST) system using hot steam at temperatesure $95{ }^{\circ} \mathrm{C}$ with holding time for 5 seconds after that The The pasteurized Juice failed in vole packages is cooled to $32{ }^{\circ} \mathrm{C}$.

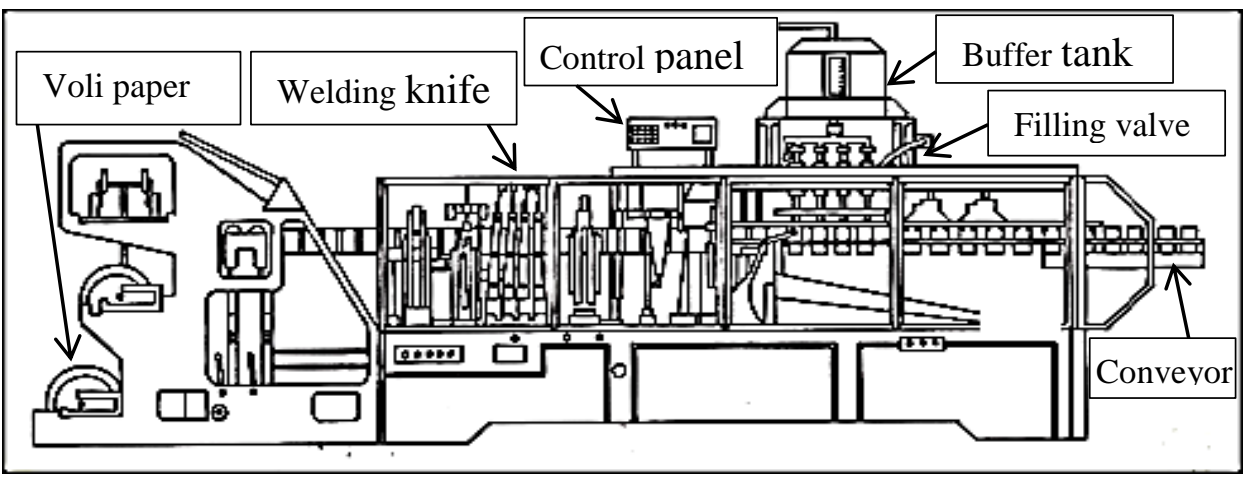

Fig. (2): Vole pack machine

\section{Packaging depart and losses:}

The hot juice pumped to volpack machine, it is coming from the uniflex heater to the buffer tank, the voli paper enter the machine and welded by axial and horizontal knife to form the voli packages, packages filled by two valves and completed by other two valve then the packages closed from the top by welding knife and get out from machine by stainless steel conveyor to the tunnel of cooling in package.The packages enter to the tunnel on a flat belt conveyor and sprayed by cooling water by the way of nozzles and it get out from the tunnel at temperatesure $32{ }^{\circ} \mathrm{C}$ then packaged in carton boxes manually. Finally the product led to storage. 


\section{Automatic vacuum filler/capper: - Fig (3)}

The machine packages liquid food in in round glass bottles volume 200 $\mathrm{ml}$ with capacity from 1000 to 8000 bottle/hour, $(-2 \%+5 \%)$ per hour and volumes available were $200 \mathrm{ml}$ Its frame was made from stainless steel and hardened glass fixed on it. The machine components, are unscramble turn table, stainless steel filler conveyor, washing glass applicator with mechanical arm, six filling nozzles, vacuum pump, three capper star wheels, buffer tank with level control, temperature control unit, capper unit, capper conveyor, panel unit and crown unit. In this study the experiments were carried out on AUV mango and apple juice for volumes $200 \mathrm{ml}$ Juice pasteurization by (HTST) system using hot water at temperature of $90{ }^{\circ} \mathrm{C}$ with holding time 25 seconds in (PHE) device then by (LTLT) system for 30 minutes at temperature $82.5^{\circ} \mathrm{C}$ at first stage then $60{ }^{\circ} \mathrm{C}$ in the second stage after that the bottles sprayed by cooling water in third stage and the glasses get out from tunnel at temperatesure $35{ }^{\circ} \mathrm{C}$.

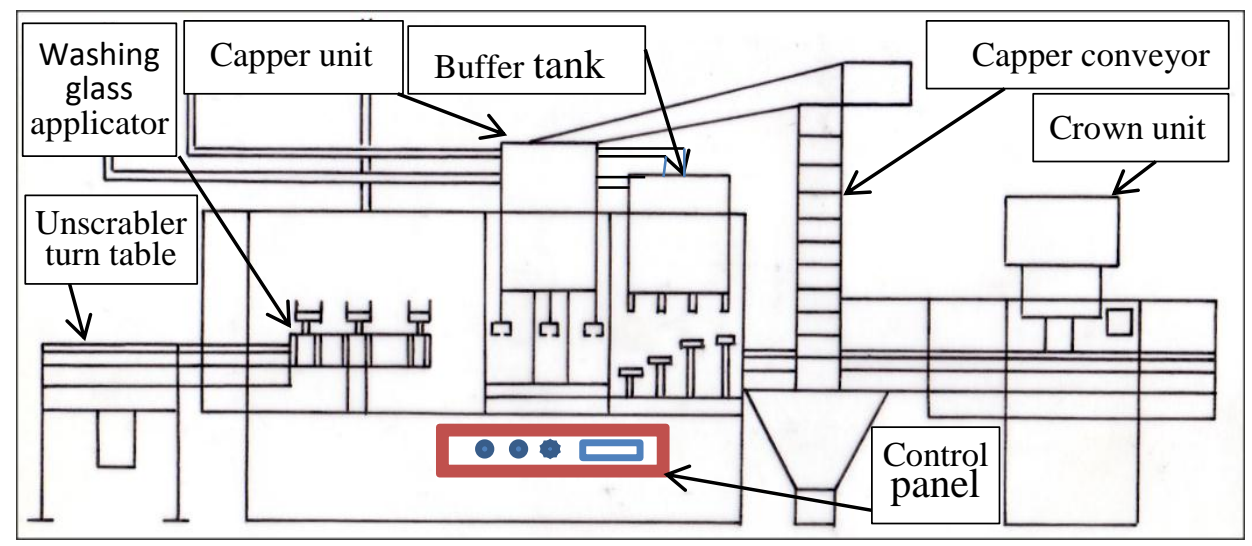

Fig. (3): Automatic vacuum filler/capper machine

\section{Packaging depart and losses:}

The juice is heated in (PHE) device to the pasteurization temperatesure $90{ }^{\circ} \mathrm{C}$ from $15{ }^{\circ} \mathrm{C}$ then the hot juice pumped to automatic vacuum filler/capper machine.Glass bottle put on unscrambler turn table and bottles will enter to filling by stainless steel conveyor, the bottle neck holded by two index arms. They are washed by hot water, conveyor will stop and valves move down on the top of bottles neck, then the juice will 
start flow to the bottles, after filling cycle complete the outer index will open and conveyor start to transport filled bottles to capping through capping star wheel one by one then the capping head move down on the top of bottle to close pilfer proof cap around the bottle neck, capping head designed to work on $28 \mathrm{~mm}$ aluminum caps, the juice fill at $85{ }^{\circ} \mathrm{C}$ in round glass bottles volume $200 \mathrm{ml}$ the filled bottles transported by flat belt conveyor to a tunnel of keep heating and cooling device. The glasses get out from tunnel at temperatesure $35^{\circ} \mathrm{C}$ transported by conveyor and dried from water by air drier then the bottle enter labeling machine, glass bottles enter on the table of machine and with elastic conveyor to put the sticker on it, transported by conveyor to shrink machine where the bottles packaged manually in boxes on the table of machine, the boxes enter to the shrink machine to be wrapped by plastic cover, finally the product led to storage.

\section{Plant C:-}

\section{Vole pack machine: - Fig (2)}

The machine packages liquid food in vole packages and with filler capacity ranged from 3000 to $4000(-0 \%+5 \%)$ per hour and volumes available were $130 \mathrm{ml}$ and $200 \mathrm{ml}$. In this study the experiments were carried out on VP apple juice. Juice pasteurization by (LTLT) system for 40 minutes at temperature $90{ }^{\circ} \mathrm{C}$ using hot steam at temperature of $120{ }^{\circ} \mathrm{C}$ after that the pasteurized Juice failed in vole packages is cooled to $32{ }^{\circ} \mathrm{C}$.

\section{Packaging depart and losses:-}

Juice preparing by crushing the pulp and putting it with sugar to cooker and preparing tanks, then water is added in tanks with a double jacket to quick dissolution with continuous mechanical mixing and heating by hot steam directly at temperatesure $120^{\circ} \mathrm{C}$, the preparing juice take about 40 minutes and the solution temperatesure is raises to $90{ }^{\circ} \mathrm{C}$. There are two cooker and preparing tanks for each volpack machine. The hot liquid juice pumped to the volpack machine then packages filled and get out from machine by stainless steel conveyor to the tunnel of cooling in package. The packages get out from the tunnel at temperatesure of $32{ }^{\circ} \mathrm{C}$ then packaged in carton boxes manually. 


\section{Instrumentations devices.}

\section{Temperature instruments:}

Digital multi-meter 1000 Model MY60 series hand held DMM Instruments with a thermocouple was used for monitoring temperature with an accuracy of $(+1.0 \%)$ and at ranged from- $20{ }^{\circ} \mathrm{C}$ to $\left.1000{ }^{\circ} \mathrm{C}\right)$ by reading liquid crystal display (LCD).

\section{Packages losses and machine rateses:}

packages rateses counter in the packaging machine control panel unit.

\section{Mass flow rates:}

rateses counter in the packaging machine control panel unit.

\section{MEATHDOLOGY:-}

This research was conducted to Accounting and comparing volumes of damaged packages, quantity of product and electrical power losses in packging processes from tetra brick aseptic packaging machine for two product including TP (mango juice 200 and $1000 \mathrm{ml}$ ) by using six different rates in plant (A) while two different product including VP 240 a (mango and apple juice) by using five different ratese packaging system such as (mango juice 130, $200 \mathrm{gm}$ and apple juice 130,200 gm) and two product including AUV (mango juice 200 and apple juice $200 \mathrm{ml}$ ) by using five packaging rates also in plant (B) in addation to one product including VP (apple juice 130 and $200 \mathrm{ml}$ ) by using five packaging ratese in plant (C). On this study Quantity losses packages, juice and electrical power in plant

\section{Data collection points:}

\section{The available data was divided in two groups:}

\section{1- recorded data 2- Measured data}

recorded of daily shafts packages product volume; packages losses product, worker shafts time and quantity of product losses.

Measured of tetra brick aseptic (TP), vole pack (VP) and Automatic vacuum filer/capper (AUV) packaging machine rateses on different rateses by packages ratese counter on panel unit to determine the ratesio of damaged packages and product losses and comparing the ratesio of losses from mango and apple juice in different speed used by Packaging 
machine to be arrived to the best speed which reduce the damaged packages and product losses.

These informations were analyzed .

\section{Packaging Losses Calculations:-}

Hanafy (2015) calculated the packaging lossses with a model depend on packaging machine rates and packaging machine product.

\section{1- The percent of damaged or losses packagesor bottels was calculated using the following formula :}

$$
\begin{aligned}
& \% \mathrm{TP}_{\mathrm{L}}=\frac{\mathrm{TP}_{\mathrm{R}}-\mathrm{TP}_{\mathrm{P}}}{\mathrm{TP}_{\mathrm{R}}} \times 100 \longrightarrow(1) \\
& \text { where } \\
& \mathrm{TP}_{\mathrm{R}}=\text { Packaging machine rates (pack. Or bottle/h) } \\
& \mathrm{TP}_{\mathrm{P}}=\text { Packaging machine product (pack. Or bottle/h) }
\end{aligned}
$$

\section{2- The percent of quantity juice losses}

$$
\begin{aligned}
& \% \mathrm{q}_{\mathrm{ML}}=\frac{\mathrm{q}_{\mathrm{M}}-\mathrm{q}_{\mathrm{MP}}}{\mathrm{q}_{\mathrm{M}}} \times 100 \longrightarrow(2) \\
& \text { where } \\
& \mathrm{q}_{\mathrm{M}}=\begin{array}{l}
\text { Quantity of juice processed to package at the same } \\
\text { machine rates }(\mathrm{lit} / \mathrm{h})
\end{array} \\
& \mathrm{q}_{\mathrm{MP}}=\begin{array}{l}
\text { Quantity of juice packaged at the same } \\
\text { machine rates }(\mathrm{lit} / \mathrm{h})
\end{array}
\end{aligned}
$$

\section{3- Electrical power losses in packaging procsses :-}

The electrical power losses model used to calculated the electrical energy losses in packaging process depanding on the percent of losses packages or bottles and the machine electrical power consumption during production with ( $\mathrm{k} . \mathrm{w} / \mathrm{hr})$ in different rateses.

$$
\mathbf{E}_{\cdot P L}=T P_{L} \times M_{P L}
$$

E.PL $=$ Electrical power losses in packaging procsses ( k.w/hr)

$\mathrm{M}_{\mathrm{PL}}=$ machine electrical power consumption during production $(\mathrm{k} . \mathrm{w} / \mathrm{hr})$ 
Table (1): Comparison between machine types electrical power consumption during production in plants (A,B and $\mathrm{C}$ ).

\begin{tabular}{||c|c|c||}
\hline \hline PLANT NAME & MACHINE TYPES & M $_{\text {PL }}$ k.w/hr) \\
\hline \hline \multirow{2}{*}{ PLANT ( A ) } & T.P $200 \mathrm{ml}$ & 22 \\
\cline { 2 - 3 } & T.P $1000 \mathrm{ml}$ & 20 \\
\hline \multirow{2}{*}{ PLANT ( B ) } & V.P 240 & 12.80 \\
\cline { 2 - 4 } & A.U.V & 18 \\
\hline PLANT ( C ) & V.P & 12 \\
\hline
\end{tabular}

\section{RESULTS AND DISSCUATIO}

\section{The packaging process losses in plants $(\mathrm{A}, \mathrm{B}$ and $\mathrm{C})$ :}

The tetra pak packages,vole pack packages and glasses bottles damaged during produced three product were tetra pack, vole pack and glasses bottels juice and energy losses in this packages by different system in plants (A,B and C) where determined and compared in different machine rates.

\section{1-Packages losses from tetra brick aseptic packaging machine in plant A:}

Fig.(4 and 5) showed the damaged packages and losses of mango juice by tetra brick aseptic packaging machine for packaging UHT mango juice in plant A in tetera brick aseptic prortion packages volumes of $200 \mathrm{ml}$ and 1 liter under six speeds of packaging. It is noticed that percentage of damaged packages were $3 \%, 1.10 \%, 3.20 \%, 2.80 \%, 1.60 \%$, and $2 \%$ while the losses of mango juice with a percentage of were $3 \%, 3.28 \%, 2.98 \%$, $3.04 \%, 3.45 \%$, and $2.90 \%$ under packaging speeds of $6120,6300,6480,6540$, 6660 and 7680 respectively for volume of $200 \mathrm{ml}$ and they were $2.50 \%$, $1 \%, 1.31, \% 3.30 \%, 1.40 \%$, and $2.30 \%$ while the losses of mango juice with a percentage of were $4.60 \%, 1.03 \%, 2.22 \%, 2.25 \%, 1.28 \%$, and $2.32 \%$ under packaging speeds of 5220, 5460, 5520, 5760, 5880 and 6120 respectively for volume of $1000 \mathrm{ml}$.From that it can be observed that the highest valu of damaged packages and lowest one were recorded in the case of using speeds of 6480 and 6300 for $200 \mathrm{ml}$ and under speeds of 5760 and 5460 respectively for one litter volume. 


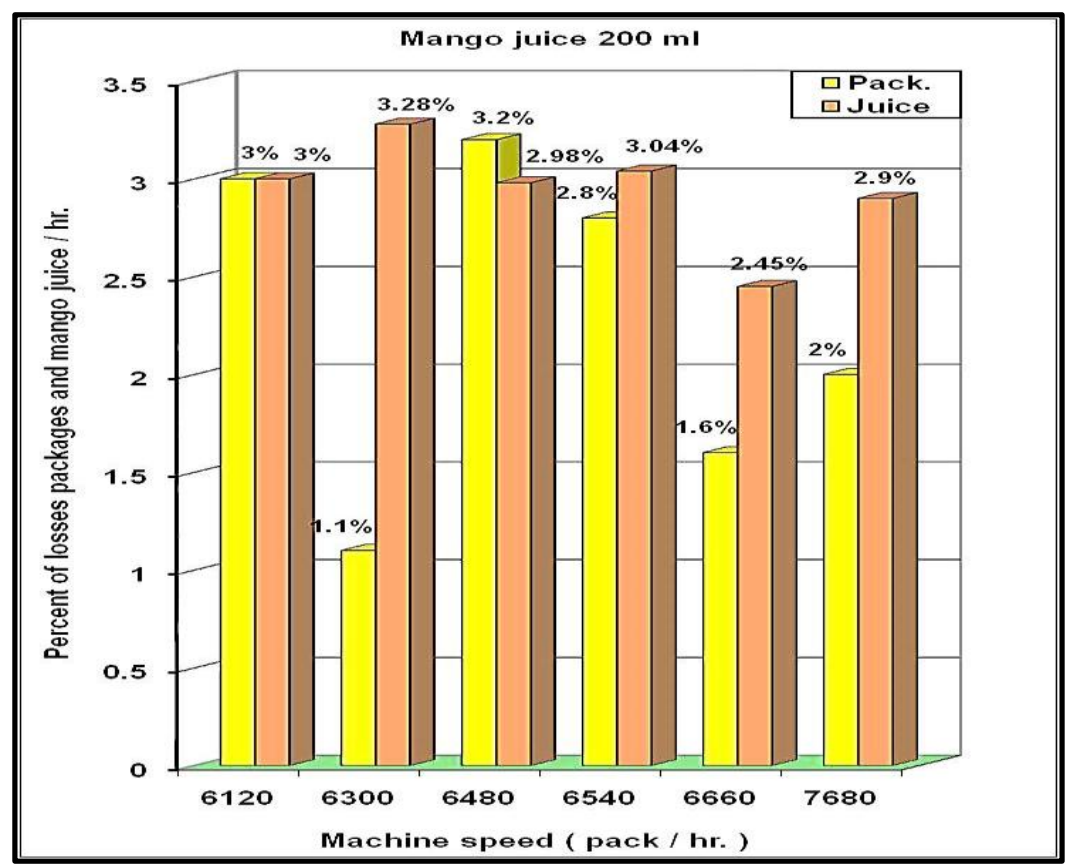

FIG.(4): Comparison between different rates of ( Tp. $200 \mathrm{ml}$ ), damaged packages and losses mango juice in plant ( $A$ ).

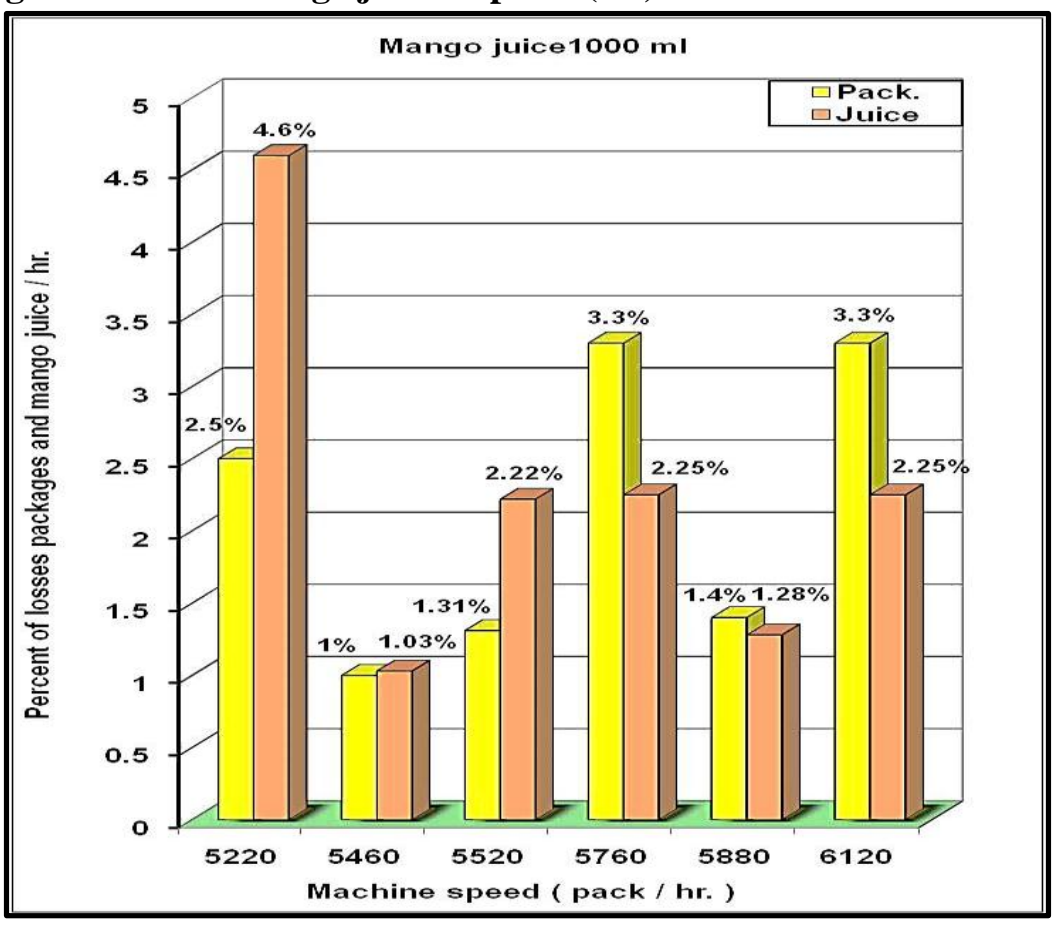

FIG.(5): Comparison between different rates of ( Tp. $1000 \mathrm{ml})$, damaged packages and losses mango juice in plant ( A ). 
2- Packages losses from Vole pack (240) packaging machine in plant (B):-

Damaged packages and losses juice by vole pack packaging machine 240 for packaging HTST mango and apple juice in plant B in vole pack packages packages wheights were $130 \mathrm{gm}$ and $200 \mathrm{gm}$ using five speeds of packaging

\section{2-1Vole pack (240) packaging machine mango juice130 and $200 \mathrm{gm}$ :}

From Fig.(6 and 7) it is cleared that the use of speed of 5160, 5400, 5460, 5520 and 5700 was accompanied with percentage of damaged packages were $5.14 \%, 2.43 \%, 1.43 \%, 1.56 \%$ and $2.26 \%$ for mango juice with volume of $130 \mathrm{gm}$ and juice losses of $2.82 \%, 4.46 \%, 2.33 \%, 2.15 \%$ and $4.47 \%$ respectively.

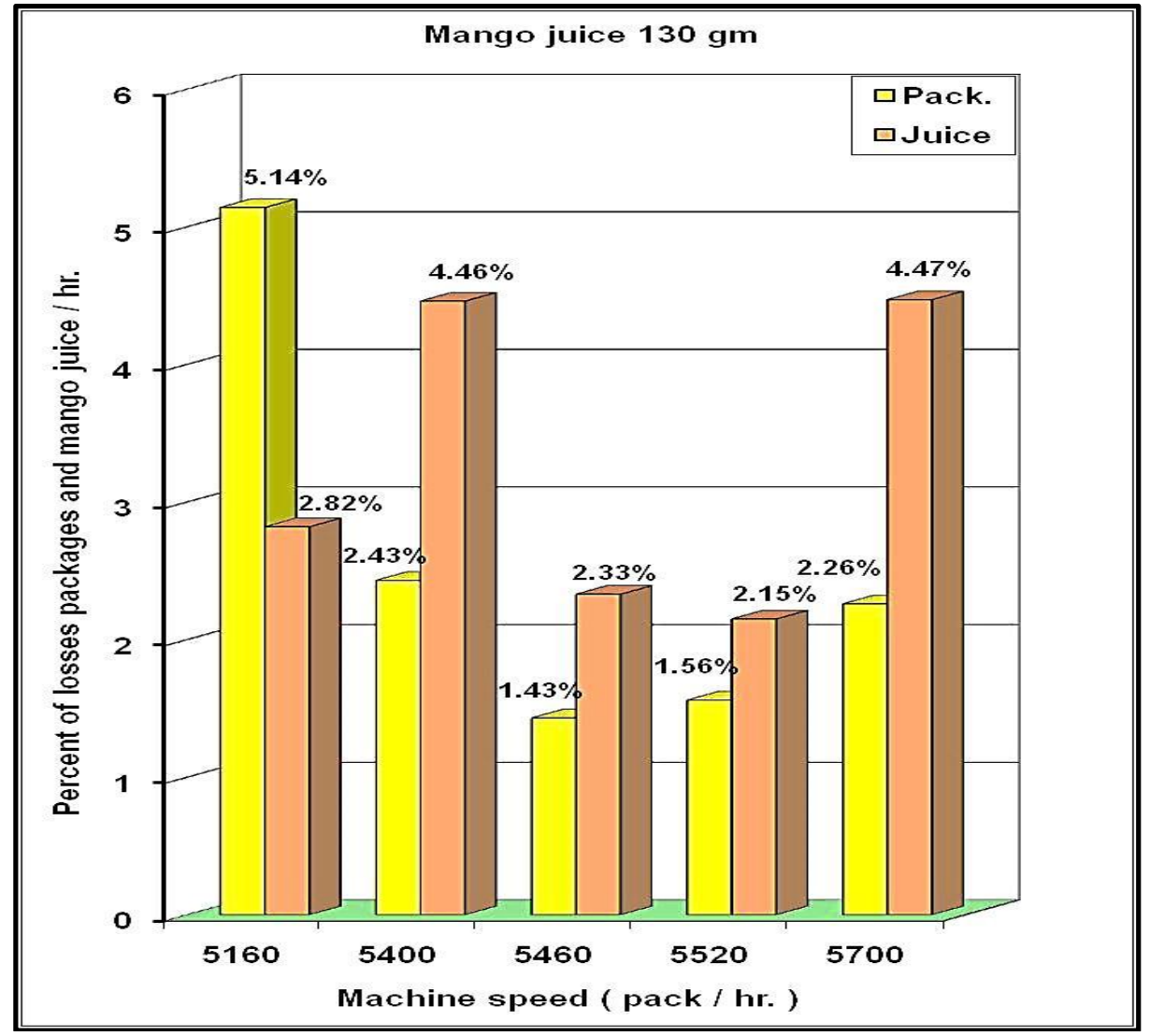

FIG.(5): Comparison between different rates of (VP. 240 , 130 gm), damaged packages and losses mango juice in plant ( $B$ ). 
Under the mentioned speeds 4560, 4800, 4860, 4920 and 5100 the damaged values were $4.80 \%, 1.81 \%, 1.75 \%, 3.46 \%$ and $5.22 \%$ while the losses recorded $2.81 \%, 1.40 \%, 4 \%, 1.43 \%$ and $3.90 \%$ respectively for volume 200 gm. It can be observed that the highest valu of damaged packages and lowest one was accompanied with a speed were recorded in the case of using speeds of 5160 and 5520 for volume of $130 \mathrm{gm}$ and under speeds of 5100 and 4860 for volume of $200 \mathrm{gm}$ respectively.

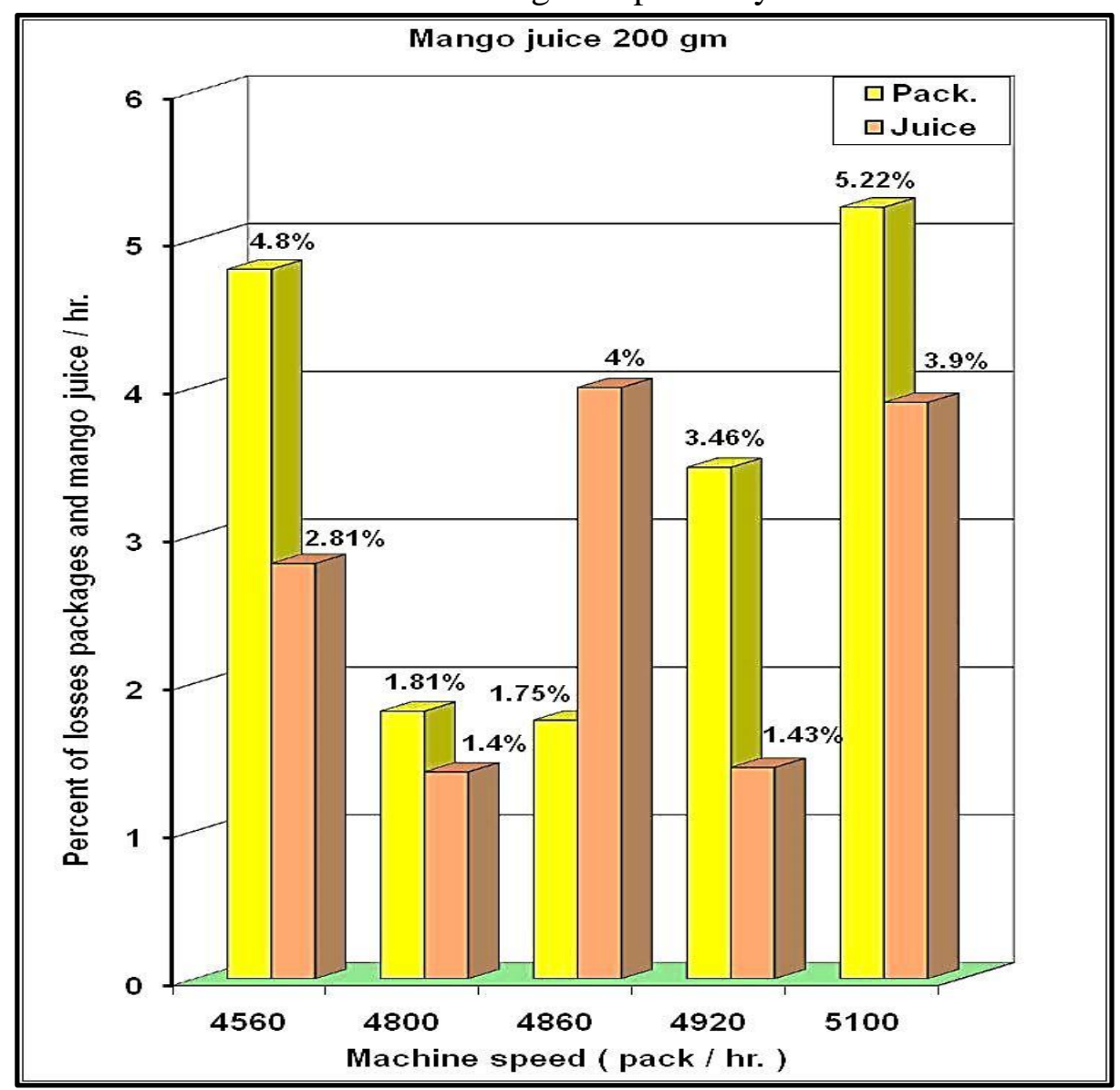

FIG.(6): Comparison between different rates of (VP. $240,200 \mathrm{gm})$, damaged packages and losses mango juice in plant ( $B$ ).

2-2 Vole pack(240) packaging machine apple juice130 gm and 200 gm in plant $(\mathbf{B})$ :

Fig.(8 and 9) cleared that that the use of speed of 5220, 5460, 5520, 5580 and 5640 was accompanied with percentage of damaged packages were 
$2.16 \%, 1.87 \%, 1.55 \%, 1.80 \%$ and $2.14 \%$ for apple juice with volume of 130 $\mathrm{ml}$ and juice losses of $2.27 \%, 2.15 \%, 2.67 \%, 5.28 \%$ and $3.53 \%$ respectively..Under the mentioned speeds 4500, 4680, 4800, 5040 and 5640 the damaged values were $5.76 \%, 3.50 \%, 2.23 \%, 4.19 \%$ and $5.77 \%$ while the losses recorded $24.63 \%, 4.30 \%, 1.65 \%, 5.55 \%$ and $4.65 \%$ respectively for volume $200 \mathrm{gm}$. The highest valu of damaged packages and lowest one was accompanied with a speed were recorded in the case of using speeds of 5220 and 5520 for volume of $130 \mathrm{gm}$ and under speeds of 5640 and 4800 respectively.

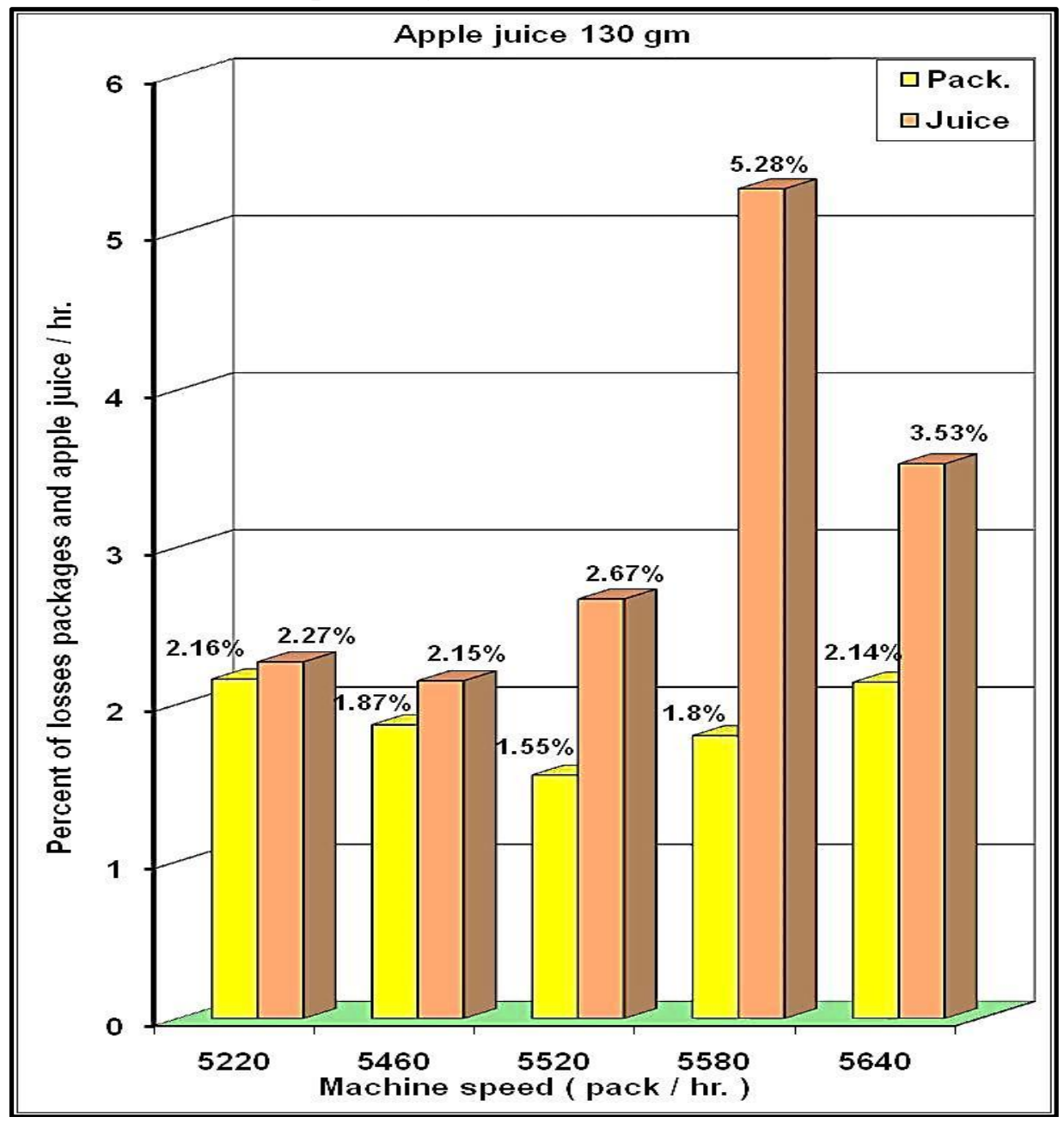

FIG.(8): Comparison between different rat of (VP. $240,130 \mathrm{gm})$, damaged packages and losses apple juice in plant ( $B$ ). 


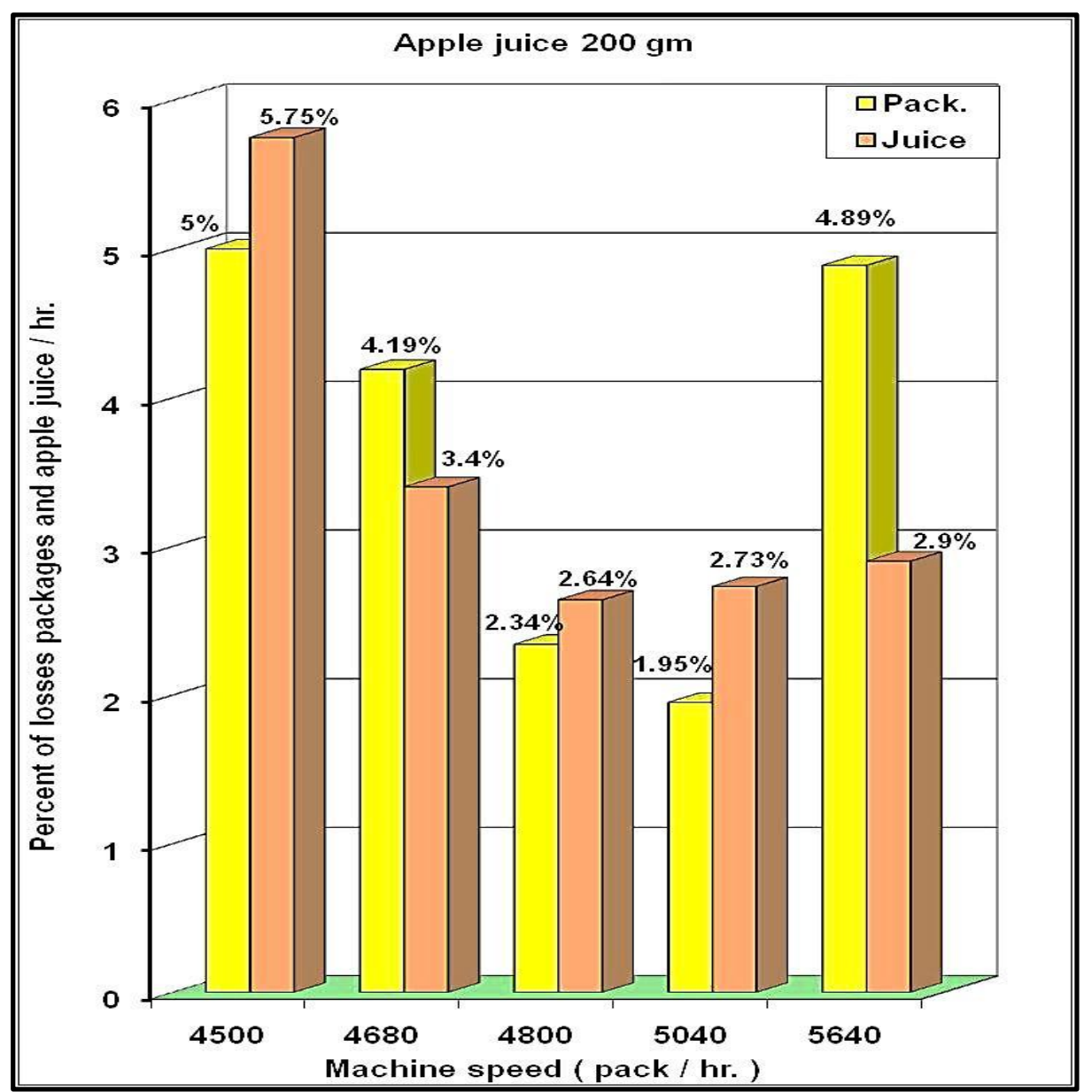

FIG.(9): Comparison between different rates of (VP. 240 , $200 \mathrm{gm}$ ), damaged packages and losses apple juice in plant ( $B$ ).

\section{2-3 Bottles damaged from Automatic vacuum filer/capper packaging machine in plant $B$ :}

Fig.(10 and 11) showed the damaged bottles, caps and losses of mango juice by automatic vacuum filer/capper packaging machine for packaging LTLT mango and apple juice in plant B in plant A in glasses bottles volumes were $200 \mathrm{ml}$ under five speeds of packaging. It can noticed that percentage of damaged bottles were $1.17 \%, 1.15 \%, 0.82 \%, 0.63 \%$ and $0.51 \%$ while the percentage of damaged caps were $3.30 \%, 4 \%, 5.24 \%, 7.24 \%$ and $8.28 \%$ in addition to losses of mango juice with percentage of $9.26 \%, 10 \%, 4.78 \%$, $3.33 \%$ and $5.11 \%$ under packaging speeds of 3000, 3120, 3300, 3480 and 
3540 respectively for mango juice $200 \mathrm{ml}$ and they were $1.48 \%, 0.99 \%$, $0.58 \%, 0.48 \%$ and $0.44 \%$ while the percentage of damaged caps were $3.81 \%, 5.65 \%, 6.04 \%, 6.23 \%$ and $6.53 \%$ in addition to losses of apple juice with percentage of $12.33 \%, 5.70 \%, 3.92 \%, 5.08 \%$ and $2.65 \%$ under packaging speeds of 3180, 3240, 3300, 3360 and 3420 respectively for apple juice $200 \mathrm{ml}$. From that it can be observed that the highest valu of damaged bottles and lowest one were recorded in the case of using speeds of 3000 and 4860 for mango juice $200 \mathrm{ml}$ and under speeds of 3180 and 3420 respectively for apple juice $200 \mathrm{ml}$.

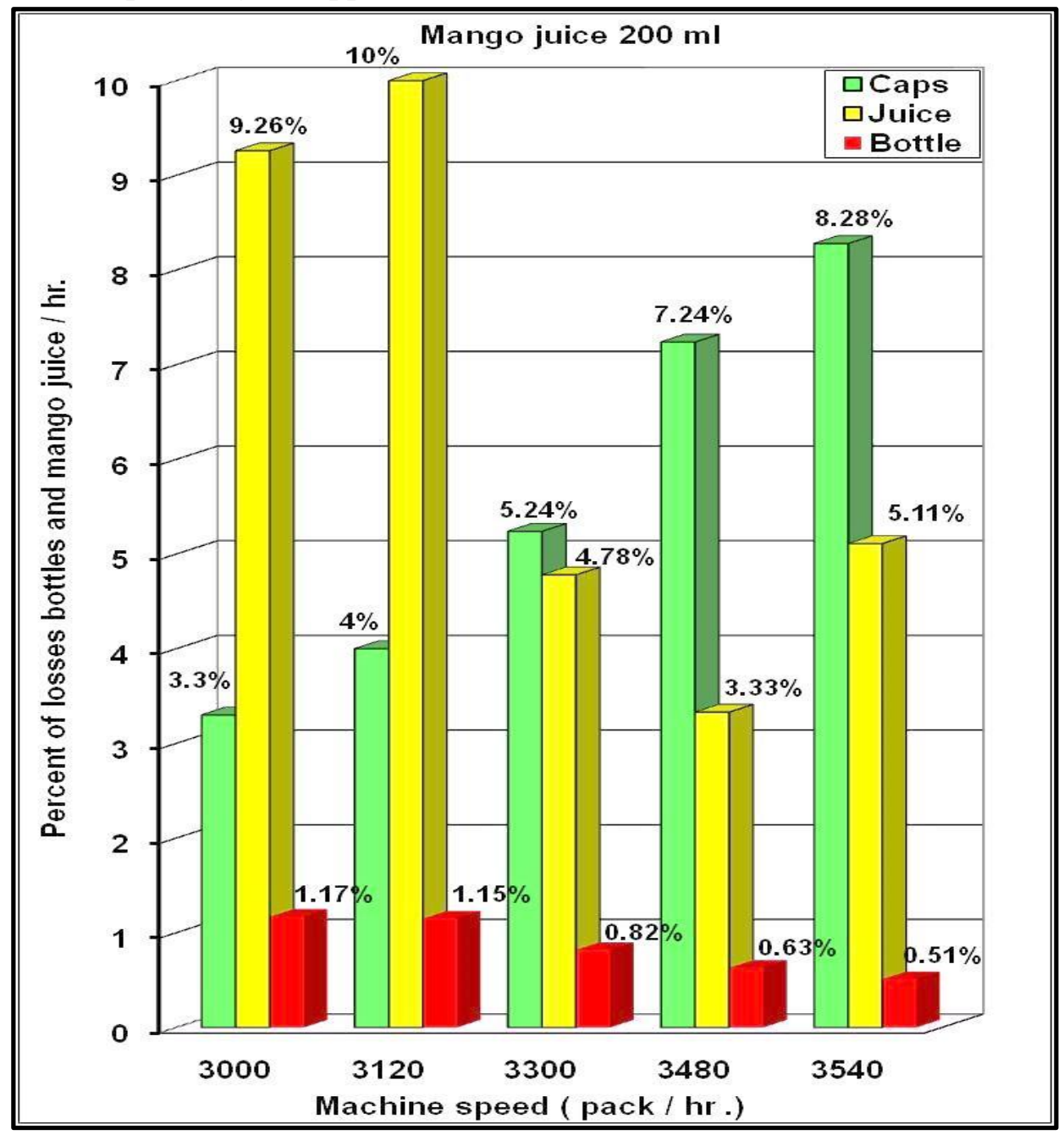

FIG.(10): Comparison between different rates of (AUF. $200 \mathrm{ml}$ ), damaged bottles and losses mango juice in plant $(\mathrm{B})$. 


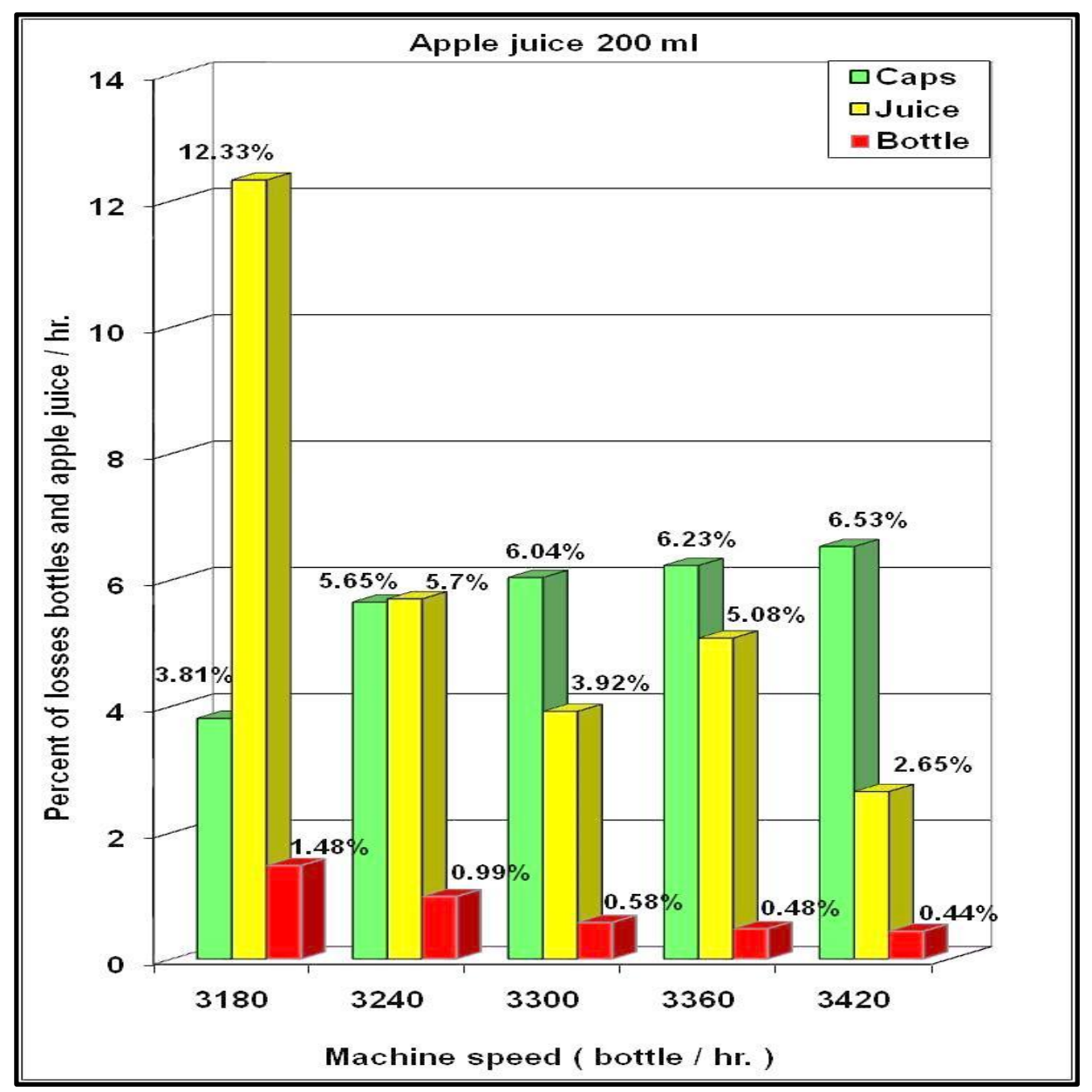

FIG.(11): Comparison between different rates of (AUF. $200 \mathrm{ml}$ ), damaged bottles and losses apple juice in plant ( $B$ ).

3- packages losses from Vole pack packaging machine in plant $(\mathrm{C})$ :

Fig.(12 and 13) showed the Damaged packages and losses juice by vole pack packaging machine packaging HTST apple juice in plant $\mathrm{C}$ in vole pack packages volumes were $(130 \mathrm{ml}$ and $200 \mathrm{ml})$ using five speeds packages for packaging. It is noticed that percentage of damaged packages were $3.90 \%, 3.60 \%, 1.02 \%, 1.39 \%$ and $2.03 \%$ while the losses of apple juice with a percentage of were $3.97 \%, 3.80 \%, 2.12 \%, 1.15 \%$ and $3.37 \%$ under packaging speeds of 3000, 3060, 3240, 3600 and 3840 respectively for volume of $130 \mathrm{ml}$ and they were $3360,3420,3540,3600$ and 3720 while the losses of apple juice with a percentage of were $3.22 \%$, 
$2.96 \%, 1.76 \%, 2.36 \%$ and $1.92 \%$ under packaging speeds of $3360,3420,3540$, 3600 and 3720 respectively for volume of $130 \mathrm{ml}$.From that it can be observed that the highest valu of damaged packages and lowest one were recorded in the case of using speeds of 3000 and 3240 for $200 \mathrm{ml}$ and under speeds of 3360 and 3540 respectively for $200 \mathrm{ml}$ volume.

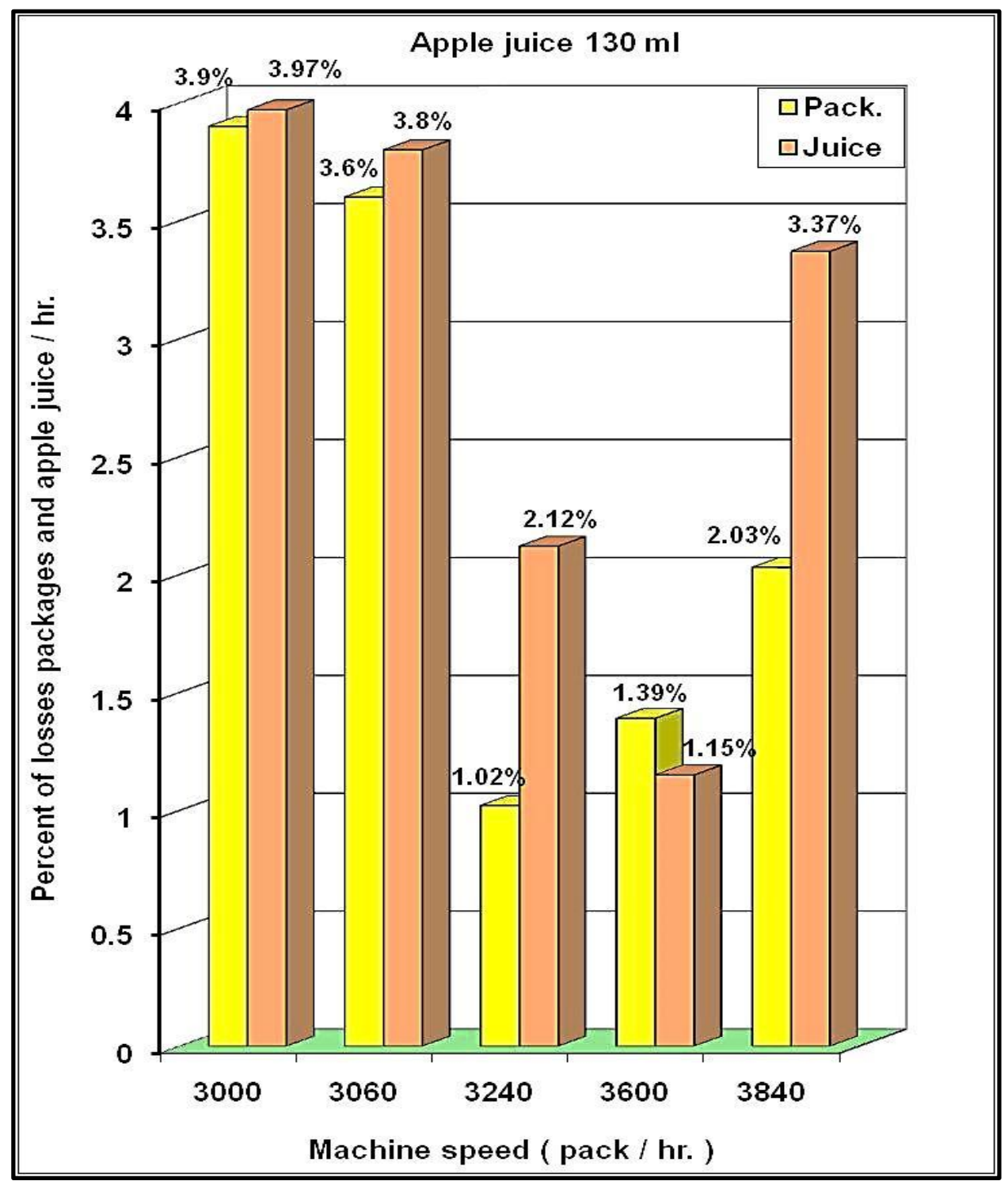

FIG.(12): Comparison between different rates of (VP.130 ml), damaged packages and losses apple juice in plant ( $\mathrm{C}$ ). 


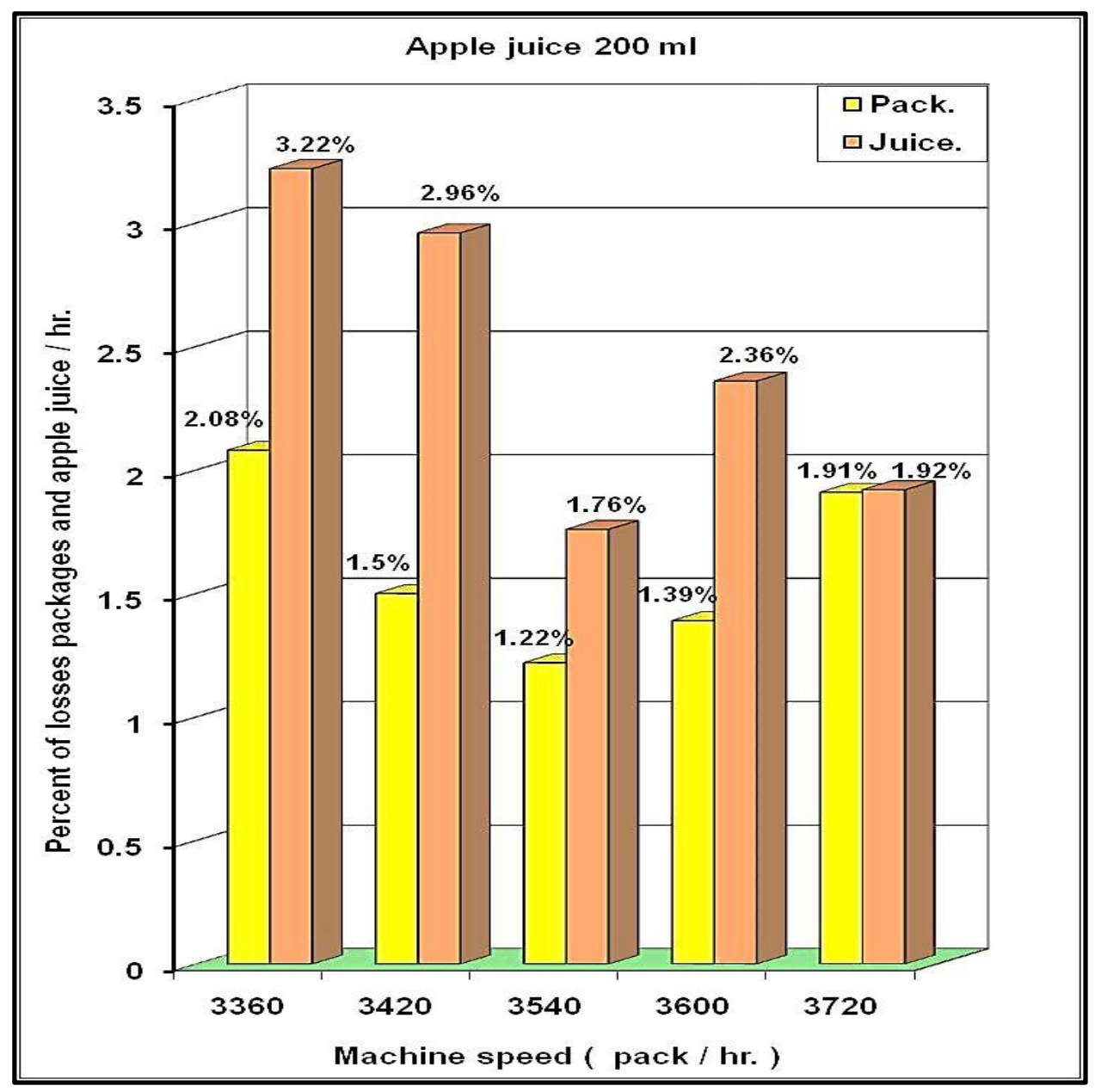

FIG.(13): Comparison between different rates of (VP. $200 \mathrm{ml})$, damaged packages and losses apple juice in plant $(\mathrm{C})$.

\section{CONCLUSION}

To reduce the percentage of damaged package process and losses juice, the system of package should be conducted under package speeds ranged from 6660 to 6300 and from 5460 to 5880 for tetra pack system 200 and $1000 \mathrm{ml}$ in plant A respectively while it should be from 5460 to 5520 and from 4800 to 4920 for VP.240 mango juice 130 and $200 \mathrm{gm}$, and from 5460 to 5520 and from 4800 to 5040 for VP.240 apple juice 130 and 200 gm and from 3480 to 3540 and from 3300 to 3420 for AUV mango and apple juice $200 \mathrm{ml}$ in plant $\mathrm{B}$ respectively, and finally it should be from 
3240 to 3600 and from 3540 to 3600 for VP. apple juice 130 and $200 \mathrm{ml}$, in plant $\mathrm{C}$ respectively.

\section{REFERENCES}

Dairy-technology. (2014) http://dairy-technology.blogspot.com/2014/01/ milk-losses-in-dairy-plants.html

E.E.A.A.I.M.(2015)http://industry.eeaa.gov.eg/publications/arDairy\%252 0IM.pdf Egyptian Environmental Affairs Agency Inspection Manual For the manufacture of dairy products (2015).

Hanafy W.M. (20015). Milk and vita chasse packaging losses in a dairy plant. Misr J. Ag. Eng., 32 (3): 1121 - 1142.

http: // wikieducator.org / Food__ Packaging _ Technology, this page was modified on 29 September 2008.

Jean-P.B. (2016) Minimizing production losses in the food and beverage.industry/http://www.designworldonline.com/author/jcalho on/

Jibing; Z. and K. Timothy; (1996) Case Studies of Chinese Economic Reform Book. Capt. (7) Factory. Third edition World Bank Publications ISBN 0821322281, 9780821322284.p.p:150-167.

OVAM (2015) http://www.ovam.be/sites/default/files/atoms/files/2015Report-OVAM-Food-loss-and-packaging-DEF.pdf

UK Drinks sector (2010) Drinks Resource Maps - Summary and overview www.wrap.org.uk/retail.

UNIDO TECHNOLOGY MANUAL (2004) Small-scale Fruit and Vegetable Processing and Products.

Wikipedia (2014) http://en.wikipedia.org/wiki/Aseptic_processing 
World Packaging Organization (2012). Market statistics and future trends in global packaging. World Packaging Organization/PIRA International Ltda.P.http://www.worldpackaging.org/publications/ documents/market-statistics.pdf (Accessed 25.10.2012).

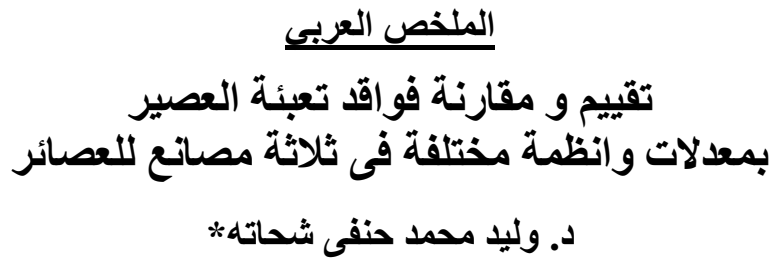

استهدف هذا البحث تقييم ومقارنة عبوات وزجاجات العصبر المفقودة و كمية العصبر المفقودة فى

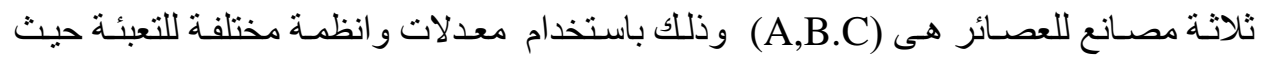

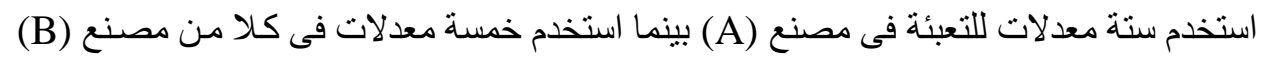
و (C) وذلك أثناء عملية تعبئة العصير بو اسطة ماكينة التتر اباك وماكينة الفولباك وماكئة وماكينة التعبئة

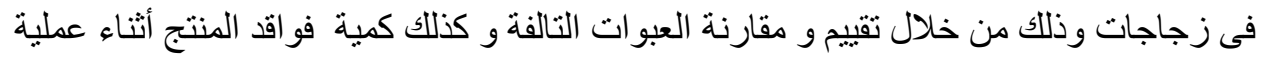

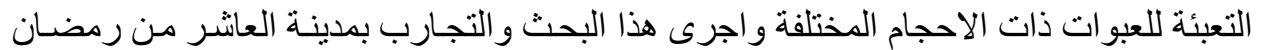

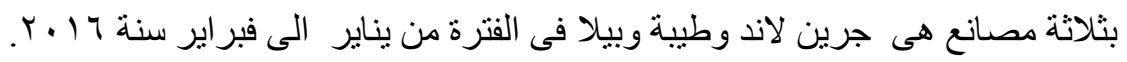

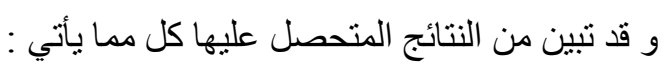

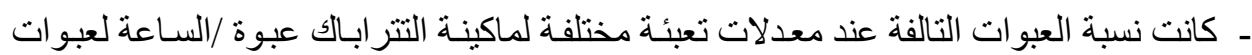

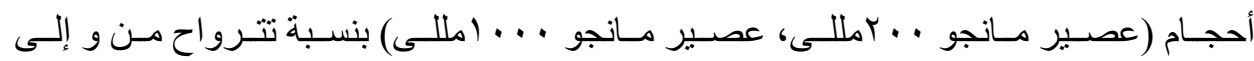

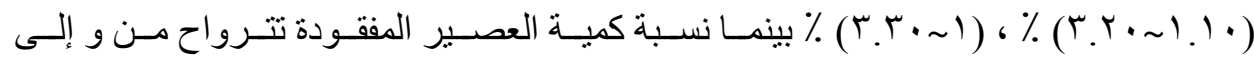

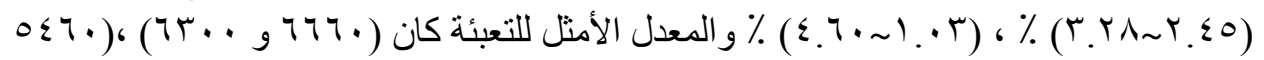

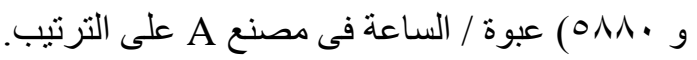

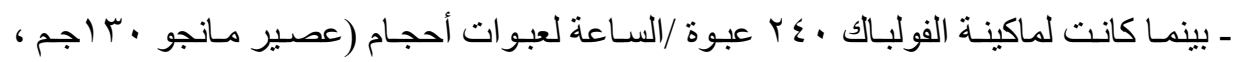

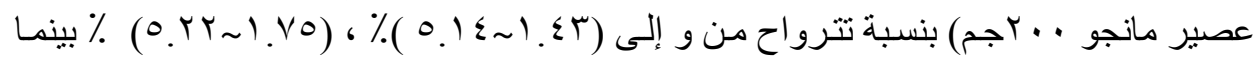

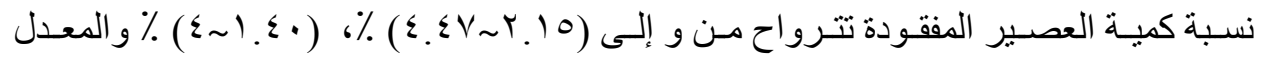

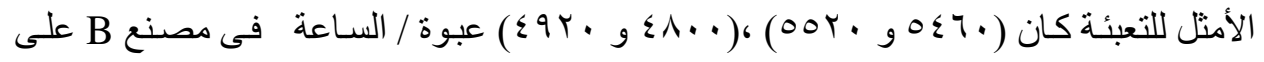
الترتيب.

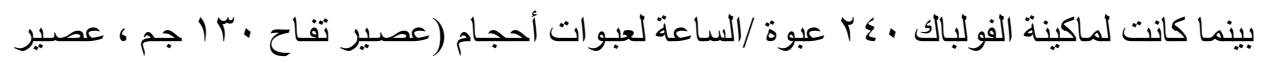

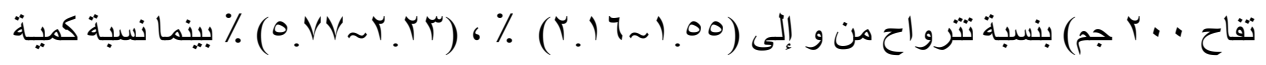

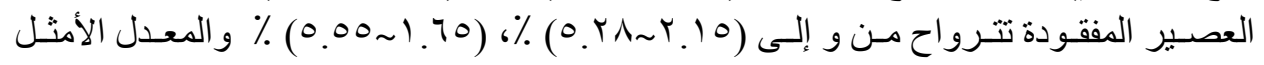
للتعبئة كان ( • * مدرس بقسم الهندسة الزراعية ـ كلية الزراعة والموارد الطبيعية - جامعة اسوان 


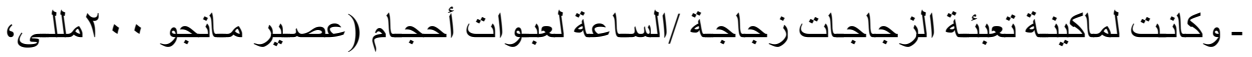

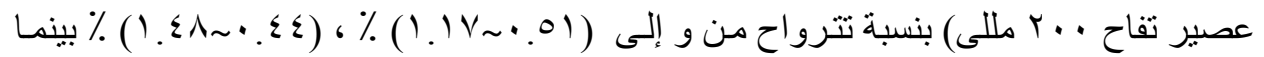

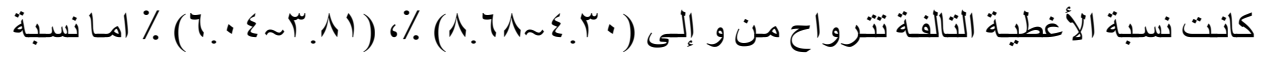

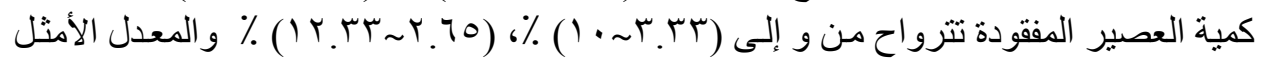

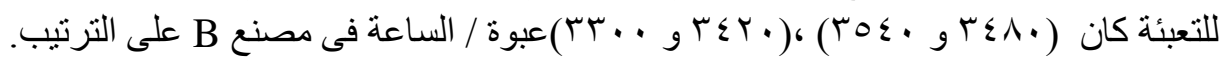

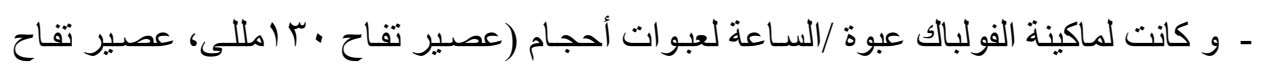

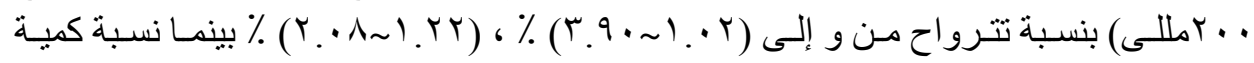

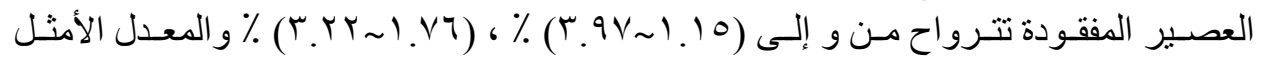

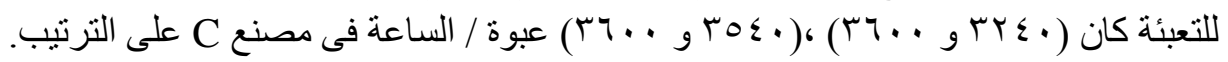

